Communication

\title{
Assessment of Natural Ageing Related Physio-Biochemical Changes in Onion Seed
}

\author{
Navjot Singh Brar ${ }^{1}$, Prashant Kaushik ${ }^{2, *}$ and Bagrawat Singh Dudi ${ }^{3}$ \\ 1 Department of Vegetable Science, Punjab Agricultural University, Ferozepur Road, Ludhiana 141027, India \\ 2 Instituto de Conservación y Mejora de la Agrodiversidad Valenciana, Universitat Politècnica de València, \\ Camino de Vera 14, 46022 Valencia, Spain \\ 3 Department of Vegetable Science, CCS Haryana Agricultural University, Main Road, Hisar 125004, India \\ * Correspondence: prakau@doctor.upv.es; Tel.: +34-9638-77000
}

Received: 24 June 2019; Accepted: 24 July 2019; Published: 25 July 2019

check for updates

\begin{abstract}
This research was performed for a period of three years to determine the effect of natural seed ageing on different physiological and biochemical changes in three extensively cultivated onion cultivars in Northern India. Seed storage studies showed that germination percent, seed viability and other seed quality parameters decreased significantly with increasing storage time. The onion seed can be stored for a maximum period of one year under ambient conditions to maintain required germination percentage $(>70 \%)$. Overall, Hisar Onion- 4 stored better when compared to Hisar Onion-3 and Hisar-2. As the ageing progressed the seed antioxidants, namely superoxide dismutase (SOD), catalase (CAT), dehydrogenase (DHA) and peroxidase (POD) decreased significantly $(p<0.05)$ in all cultivars whereas, the electrical conductivity (EC) of seed leachates increased significantly. Under the field conditions, seedling establishment percent (SE) onion seed was positively correlated $\left(\mathrm{R}^{2}=0.98 ; p<0.05\right)$ with germination percent $(\mathrm{GP})$. Overall, more than one year period of seed storage was associated with poor germination and seedling establishment potential in onion.
\end{abstract}

Keywords: ageing; antioxidants; germination; onion; seed storage

\section{Introduction}

Onion (Allium cepa L.), a member of the Alliaceae family, is one of the most important commercial vegetable crops. India ranks first in terms of area (1320.04 thousand ha) and second in production $(20,931.21$ thousand $t)$ after China with average productivity of $15.86 \mathrm{t} / \mathrm{ha}$ [1]. The productivity of onion in India is very low when compared with Ireland (30.5 t/ha), USA (66.82 t/ha), Spain (52.48 t/ha) and China (22.08 t/ha) [2]. As the area planted with onion is increasing, the demand for high-quality seed is growing [3]. Availability of viable and vigorous seed at the time of planting is of paramount importance for accomplishing production targets [4,5]. Because the cultivable area is slashing as a consequence of the ever-growing population, the increased agricultural productivity is the only alternative that could be achieved through good quality inputs [6,7]. Furthermore, the good quality seed is the primary requirement to accentuate the production along with productivity, as it increases the productivity of crop by $15-20 \%$. The seed is a living entity, and it loses its viability after a certain period of storage [8,9]. Concerning this, onion seed is classified as an orthodox and poor storer because it can't maintain viability after 1-1.5 years of storage under ambient conditions [10,11]. The significant factors affecting the seed quality during storage are temperature and relative humidity [12]. Therefore, studies are conducted to determine the actual cause of seed ageing phenomenon; in such studies, more emphasis is given on physiological and biochemical changes escorted during storage [13]. Seed ageing has been hypothesized to be caused by processes like lipid peroxidation, enzyme inactivation or decline in proteins, cell membrane disintegration and damage due to genetic factors [14-16]. The 
most important hypothesis regarding seed ageing is the degradation of enzymes due to structural changes at the macromolecular level [17-20]. Correspondingly, it has been concluded that aged seeds have reduced activity of enzymes like superoxide dismutase (SOD), catalase (CAT), and peroxidase (POD) [21]. Reduced enzyme activity in the aged seeds leads to impaired respiratory capacity, which reduces seed vigour [22]. Free radicles in ageing seeds, in the absence of these enzymes, lead to a decline in seed viability.

There is a scarcity of information on these lines for onion seed lots. Also, studies on these seed quality parameters have been mostly focused on the field crops, and such efforts are not at an adequate level in vegetable crops. In this direction, the present study was carried out to determine the physiological changes and antioxidant enzyme concentrations in fresh as well as aged onion seeds of popular cultivars from Northern India.

\section{Materials and Methods}

\subsection{Seed Material}

The freshly harvested seed of onion cultivars, namely, Hisar-2 $\left(\mathrm{V}_{1}\right)$, Hisar Onion-3 $\left(\mathrm{V}_{2}\right)$ and Hisar Onion- $4\left(\mathrm{~V}_{3}\right)$ were brought to the laboratory and stored in cloth bags under room temperature conditions $\left(27 \pm 1{ }^{\circ} \mathrm{C}\right.$, relative humidity (RH) $54 \pm 3 \%$ ) with seed moisture $7-8 \%$. This seed was used for further studies according to different years of natural seed ageing. These cultivars were selected based on their extensive cultivation and popularity among Haryana farmers in Haryana, India. Further, there were three replicates of each genotype for every parameter studied.

\subsection{Germination and Seed Viability Determination}

Germination assays were determined according to the procedure described by International rules for seed testing (ISTA) [23] by placing seeds in Petri plates for germination at $20-22{ }^{\circ} \mathrm{C}$ and $90 \pm 2 \%$ RH (100 sterilized seeds per Petri plate in four replicates) in a germination chamber. Germination (\%) was scored at radicle growth of $2 \mathrm{~mm}$, or more and counting of normal and abnormal seedlings was started on the 5th day and continued to 20th day (final count) followed by calculation of germination percentage. After the germination test, seedling length, dry seedling weight and seed vigour index were measured and calculated as per the standard procedure [17]. Seedling length $(\mathrm{cm})$ was measured from 20 randomly selected normal seedlings at time of final count of germination. These selected seedlings were then kept in a hot air oven at $60^{\circ} \mathrm{C}$ for $48 \mathrm{~h}$ for the recording of seedling dry weight $(\mathrm{mg})$. Based on the seed germination, seedling length and seedling dry weight data, seed vigour index-I (SV-I) and seed vigour index-II (SVI-II) were calculated as defined elsewhere [24]. SVI-I was estimated as the standard seed germination $(\%) \times$ seedling length $(\mathrm{cm})$. Whereas, SVI-II was calculated as the standard seed germination $(\%) \times$ dry weight $(\mathrm{mg})$. To evaluate the viability, 25 seeds were soaked in $50 \mathrm{~mL}$ water and kept in the incubator at $30 \pm 1{ }^{\circ} \mathrm{C}$ (in three replicates) for $24 \mathrm{~h}$. After incubation, seeds were cut longitudinally and maintained in $1 \%$ staining solution of 2,3,5-triphenyl tetrazolium chloride (TTC) for $4 \mathrm{~h}$ at $38 \pm 1{ }^{\circ} \mathrm{C}$ under dark conditions [25]. During the staining period, only viable part of the seed is converted into red colour due to the formation of triphenyl formazon from TTC solution.

\subsection{Accelerated Ageing Test (\%)}

100 freshly harvested seeds of each of three cultivars were taken for artificial ageing. Seeds were put into a nylon bag (having distilled water at the bottom) and placed in an accelerated ageing chamber at $40 \pm 1{ }^{\circ} \mathrm{C}$ and about $100 \% \mathrm{RH}$ for $48 \mathrm{~h}$. After the incubation, these seeds were tested for germination, according to ISTA [23].

\subsection{Electrical Conductivity Test (EC)}

The electrical conductivity of seed leachates was measured for seeds of different age. Fifty seeds were soaked in $75 \mathrm{~mL}$ deionised water and incubated at $25^{\circ} \mathrm{C}$ for $24 \mathrm{~h}$. Seed leachates were collected, 
and conductivity $(\mathrm{dS} / \mathrm{cm} / \mathrm{seed})$ was recorded by using digital conductivity meter along with deionised water as a control [26].

\subsection{Biochemical Characteristics}

For testing enzyme activity seeds of each cultivar were imbibed in a beaker at $30^{\circ} \mathrm{C}$ for $24 \mathrm{~h}$. $200 \mathrm{mg}$ of the imbibed seeds sample was ground in a chilled pestle mortar with $10 \mathrm{~mL}$ phosphate buffer ( $\mathrm{pH} 7.8$ ) and pinch of coming salt. The $10 \mathrm{~mL}$ homogenate as centrifuged at 12,000 rpm for $20 \mathrm{~min}$ at $4{ }^{\circ} \mathrm{C}$. The supernatant obtained was then recentrifuged at $15,000 \mathrm{rpm}$ for $10 \mathrm{~min}$. The clear supernatant, thus obtained, was used for estimating the activity of enzymes such as catalase (CAT), peroxidase (POD) and superoxide dismutase (SOD).

\subsubsection{Catalase Activity Test (CAT)}

The CAT activity was measured as per the procedure is given by Aebi [27], through measuring the disappearance of $\mathrm{H}_{2} \mathrm{O}_{2}\left(\varepsilon=39.4 \mathrm{mM}^{-1} \cdot \mathrm{cm}^{-1}\right)$. A $3 \mathrm{~mL}$ reaction mixture containing sodium phosphate buffer ( $50 \mathrm{mM}, \mathrm{pH} 7)$ and $10 \mathrm{mM} \cdot \mathrm{H}_{2} \mathrm{O}_{2}$ and enzyme extract from seed was prepared. The absorbance was measured at $240 \mathrm{~nm}$ in a spectrophotometer (Specord-205, Analytik Jena AG, Jena, Germany). It was expressed in terms of $\mathrm{H}_{2} \mathrm{O}_{2}(\mathrm{nmol})$ reduced as $\mathrm{nmol} \mathrm{min}{ }^{-1} \cdot \mathrm{mg}^{-1}$ protein.

\subsubsection{Peroxidase Activity Test (POD)}

Peroxidase activity (POX) was measured based on the procedure given by Rao et al. [28], by monitoring the formation of tetraguaiacol $\left(\varepsilon=26.6 \mathrm{mM}^{-1} \cdot \mathrm{cm}^{-1}\right)$ from guaiacol. The POX reaction mixture $\left(3 \mathrm{~mL}\right.$ ) containing $0.5 \mathrm{mM}$ phosphate buffer ( $\mathrm{pH}$ 6.1), $16 \mathrm{mM}$ guaiacol, $2 \mathrm{mM} \mathrm{H}_{2} \mathrm{O}_{2}$ and $20 \mu \mathrm{L}$ of enzyme extract was prepared and changes in absorbance of the reaction mixture at $470 \mathrm{~nm}$ were observed at every $30 \mathrm{~s}$. The specific activity of the enzyme was expressed as $\mu \mathrm{mol}^{-1} \cdot \mathrm{min}^{-1} \cdot \mathrm{mg}$ protein tetraguaiacol formed.

\subsubsection{Superoxide Dismutase Activity (SOD)}

The SOD activity was determined as per the procedure specified by Dhindsa et al. [29] with minor modifications. The SOD activity was estimated by estimating the decrease in optical density of formazone, made by superoxide radical and nitro-blue tetrazolium dye by the enzyme. Further, absorbance was captured at $560 \mathrm{~nm}$ using a spectrophotometer, and one unit of enzyme activity was estimated as the quantity of enzyme that reduced the absorbance reading by $50 \%$ in comparison to tubes lacking the enzyme. The specific activity of all the enzymes was expressed as units $/ \mathrm{S} / \mathrm{mg}^{-1}$ protein.

\subsubsection{Dehydrogenase Activity (DHA)}

DHA was measured as per the procedure by using $0.5 \%$ tetrazolium solution as defined elsewhere [30]. The absorbance was recorded at $480 \mathrm{~nm}$ in a spectrophotometer, and enzymatic activity was expressed as OD g${ }^{-1} \cdot \mathrm{mL}^{-1}$. The $200 \mathrm{mg}$ flour prepared was soaked in $5 \mathrm{~mL}$ of $0.5 \%$ tetrazolium chloride solution at $38^{\circ} \mathrm{C}$ for $3-4 \mathrm{~h}$. After soaking it was centrifuged at $10,000 \mathrm{rpm}$ for $3 \mathrm{~min}$ and the supernatant was discarded. The formazan from the sediment was extracted with $10 \mathrm{~mL}$ acetone for $16 \mathrm{~h}$, followed by centrifugation and absorbance of the solution was determined by Systronic spectrophotometer 169 (Systronics, Ahmedabad, India) at $480 \mathrm{~nm}$. These observations were expressed as change in $\mathrm{OD} \mathrm{g}^{-1} \mathrm{~mL}^{-1}$.

\subsection{Seedling Emergence Index (SEI)}

The number of seedlings emerged under field conditions were counted daily from 1st day to 20th day, and the seedling emergence index was calculated as described elsewhere [31]. 


\subsection{Seedling Establishment (\%)}

Seedling establishment was estimated under field conditions by including the total number of seedlings after emergence or when there was no further addition to the total emergence.

\subsection{Statistical Analysis}

The statistical significance of the cultivars and their interaction effects with the storage period, and seed quality parameters were analyzed [32]. The Pearson correlation coefficients were estimated, making use of Statgraphics Centurion XVI software (StatPoint Technologies, Warrenton, VA, USA). Whereas, the simple linear regression between seed age and quality parameters was worked out using a data analysis tool pack in MS Excel.

\section{Results}

For the study, four differentially aged seed lots of three cultivars of onion were selected, namely, $\mathrm{V}_{1}$ (Hisar-2), $\mathrm{V}_{2}$ (Hisar Onion-3) and $\mathrm{V}_{3}$ (Hisar Onion-4). Results of the different parameters under study are discussed as follows.

\subsection{Seed Physiological Parameters}

Physiological parameters of onion seed, namely, germination (\%), seedling length ( $\mathrm{cm})$, seedling dry weight $(\mathrm{mg})$ and seed viability (\%) declined with increase in the age of the seed in all of the three cultivars under study. Among the three cultivars best performing cultivar was Hisar Onion-4 $\left(\mathrm{V}_{3}\right)$. Germination of $V_{1}, V_{2} \& V_{3}$ in fresh seed (83, 83.67 and $84.67 \%$ ) reduced to $9.33,11$ and $12.67 \%$ in the four-year-old seed (Figure 1A). Due to the natural ageing, the maximum reduction in germination and viability was observed in $V_{1}$ compared to $V_{2}$ and $V_{3}$. The seed ageing leads to a gradual decrease in seedling characteristics, namely, length $(\mathrm{cm})$ and dry weight $(\mathrm{mg})$ in onion (Figure $1 \mathrm{~B}, \mathrm{C})$. The highest seedling length $\left(15.23 \mathrm{~cm}\right.$ ) was observed in $V_{1}$, while highest seedling dry weight $(3.795 \mathrm{mg}$ ) in freshly harvested seed of $V_{2}$ and $V_{3}$ cultivars, respectively. However, with the progression of the storage period, the parameters declined in all three cultivars. Onion seed viability was assessed and it was found that the freshly harvested seeds ( 0 years) showed more than $80 \%$ viability in all three cultivars which gradually declined and very low viability (11-14\%) was recorded after three years of natural ageing in all cultivars (Figure 1D). On comparative evaluation, Hisar Onion-4 (V3) showed better seed viability than other cultivars after natural ageing. The results showed that more than $40 \%$ of seeds were non-viable after 2 years of natural ageing. The reduction in germination percent (GP), seedling length (SL) and seedling dry weight (SDW) also affect the seed vigour index-I \& II accordingly (Figure 2). Due to natural ageing, the potential of seed declined significantly from 1176.82-47.71, 1274.72-62.5, and 1250.25-94.6 in $\mathrm{V}_{1}, \mathrm{~V}_{2}$ and $\mathrm{V}_{3}$ respectively.

Out of the 105 correlations, 23 were highly significant at $p<0.01$ with high absolute values $(>0.90)$, while 21 were non-significant. All the seed quality parameters, except EC has a negative correlation with seeds age (Table 1). Whereas, EC had a positive correlation with seed age but a negative correlation with all seed quality parameters. (Table 1). As the germination, seed vigour index-I, seed vigour index-II and seed viability has a robust relationship with the field parameters (seedling emergence index and seedling establishment), these can prove to be a useful indicator of field emergence. Simple linear regression of seed age on germination (Figure 3) and seed viability (Figure 4) show high fitness of models with $R^{2}$ values of 0.95 and 0.91 , respectively. Seed age explains $95 \%$ variation in germination and $91 \%$ variation in seed viability. 

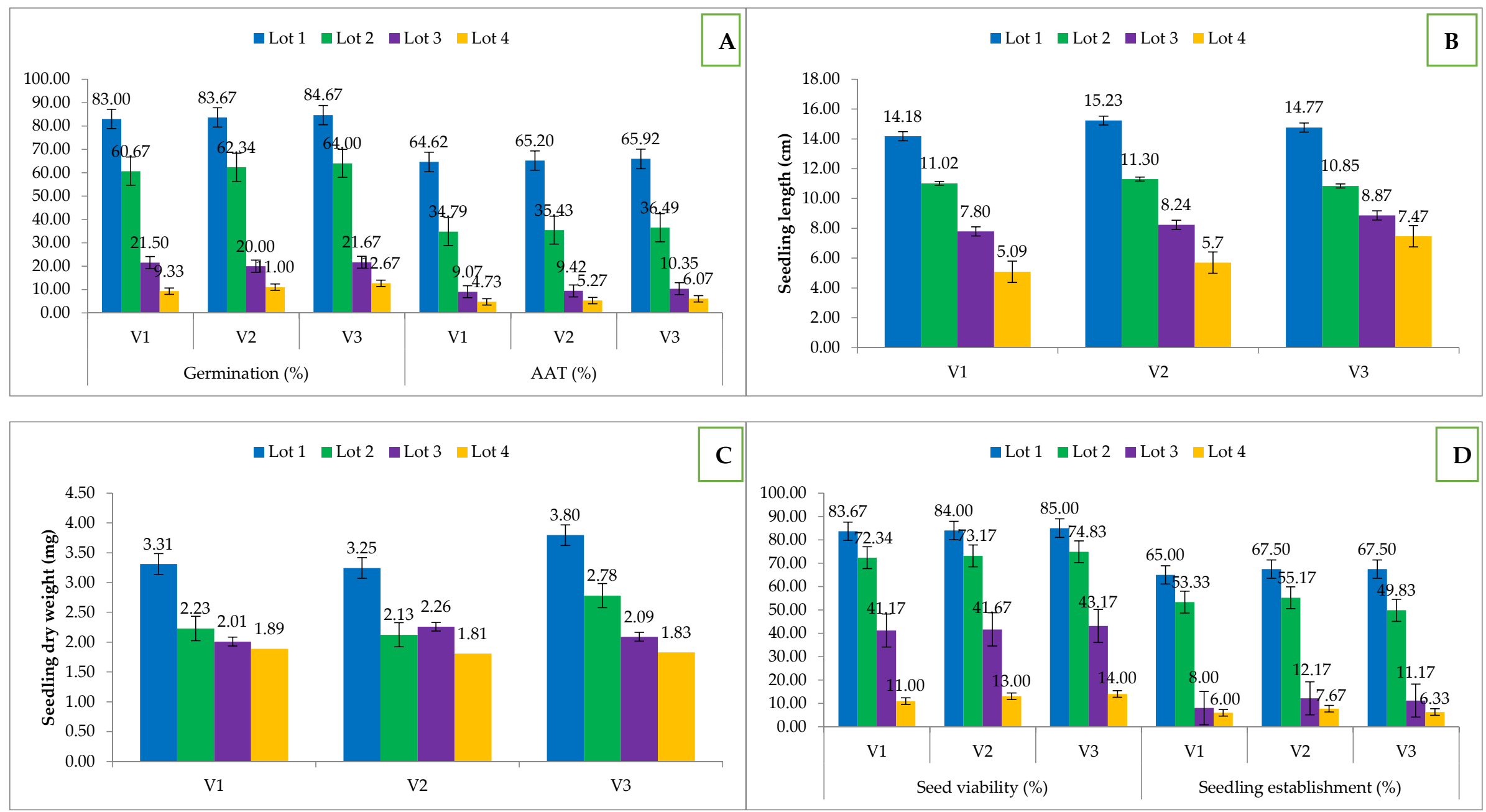

Figure 1. Effect of seed ageing on (A) germination and accelerated ageing test (AAT); (B) seedling length; (C) seedling dry weight; (D) seed viability and seedling establishment; $V_{1}-$ Hisar-2; $V_{2}-$ Hisar Onion 3; $V_{3}-$ Hisar Onion 4; Lot 1-Fresh seed; Lot 2-One-year-old seed; Lot 3-Two-year-old seed; Lot 4-Three-year-old seed. 
Table 1. Correlation matrix between age, physiological, biochemical and field parameters of onion seed.

\begin{tabular}{|c|c|c|c|c|c|c|c|c|c|c|c|c|c|c|}
\hline & Seed Age & Germination & $n \quad S L$ & SDW & SVI-I & SVI-II & SV & AAT & EC & CAT & POD & SOD & DHA & SEI \\
\hline Germination (\%) & $-0.977^{*}$ & & & & & & & & & & & & & \\
\hline $\mathrm{SL}(\mathrm{cm})$ & $-0.994 * *$ & $0.979 *$ & & & & & & & & & & & & \\
\hline SDW (mg) & $-0.933^{\mathrm{NS}}$ & $0.913^{\mathrm{NS}}$ & $0.966^{*}$ & & & & & & & & & & & \\
\hline SVI-I & $-0.967^{*}$ & $0.985 *$ & $0.987 *$ & $0.966^{*}$ & & & & & & & & & & \\
\hline SVI-II & $-0.961 *$ & $0.973 *$ & 0.985 NS & $0.978^{*}$ & $0.998 * *$ & & & & & & & & & \\
\hline SV (\%) & $-0.977^{*}$ & $1^{* *}$ & $0.98 *$ & $0.917^{\mathrm{NS}}$ & $0.987 *$ & $0.976 *$ & & & & & & & & \\
\hline AAT (\%) & $-0.96 *$ & $0.98 *$ & $0.983 *$ & 0.97 * & $1^{* *}$ & $0.999 * *$ & $0.982 *$ & & & & & & & \\
\hline EC $(\mathrm{dS} / \mathrm{cm} / \mathrm{seed})$ & $0.995^{* *}$ & $-0.992^{* *}$ & $-0.989 *$ & $-0.917^{\mathrm{NS}}$ & $-0.975 *$ & $-0.964 *$ & $-0.992 * *$ & $-0.968 *$ & & & & & & \\
\hline CAT (mg/protein/min) & $-0.948^{\mathrm{NS}}$ & $0.896^{\mathrm{NS}}$ & $0.967 *$ & $0.987 *$ & $0.94 \mathrm{NS}$ & $0.953 *$ & $0.899 \mathrm{NS}$ & $0.941^{\mathrm{NS}}$ & $-0.92 \mathrm{NS}$ & & & & & \\
\hline POD (mg/protein/min) & -1 ** & $0.978 *$ & $0.996 * *$ & $0.94^{\mathrm{NS}}$ & $0.972 *$ & $0.966 *$ & $0.978 *$ & $0.966 *$ & $-0.995^{* *}$ & $0.952 *$ & & & & \\
\hline $\mathrm{SOD}$ (mg/protein/min) & $-0.984 *$ & $0.966 *$ & $0.96 *$ & $0.854^{\mathrm{NS}}$ & 0.926 & 0.909 NS & $0.964 *$ & $0.914^{\mathrm{NS}}$ & $-0.987 *$ & $0.878^{\mathrm{NS}}$ & $0.98 *$ & & & \\
\hline DHA (OD/g/min) & $-0.998 * *$ & $0.966^{*}$ & $0.995^{* *}$ & $0.946^{\mathrm{NS}}$ & $0.965 *$ & $0.962 *$ & $0.966 *$ & $0.959 *$ & -0.988 * & $0.964^{*}$ & $0.999 * *$ & $0.973 *$ & & \\
\hline SEI & $-0.996 * *$ & $0.992 * *$ & $0.994^{* *}$ & $0.934^{\mathrm{NS}}$ & $0.983 *$ & $0.974 *$ & $0.992 * *$ & $0.977 *$ & $-0.999 * *$ & 0.934 & $0.996^{* *}$ & $0.98 *$ & $0.991 * *$ & \\
\hline SE $(\%)$ & $-0.953 *$ & $0.995^{* *}$ & $0.954 *$ & $0.877^{N S}$ & $0.971 *$ & $0.955 *$ & $0.995^{* *}$ & $0.965 *$ & -0.978 * & $0.85^{\mathrm{NS}}$ & 0.954 * & $0.952 *$ & 0.937 NS & $0.976 *$ \\
\hline
\end{tabular}

* Significant at $5 \%(p=0.05) ;{ }^{* *}$ Significant at $1 \%(p=0.01)$; NS-Non-significant; SL-Seedling length; SDW—Seedling dry weight; SVI-I-Seed vigour index I; SVI-II-Seed

vigour indexII; SV—Seed viability; AAT—Accelerated ageing test; EC-Electrical conductivity; CAT—Catalase activity; POD—Peroxidase activity; SOD-Sodium peroxidase activity; DHA—Dehydrogenase activity; SEI-Seedling emergence index; SE-Seedling establishment. 


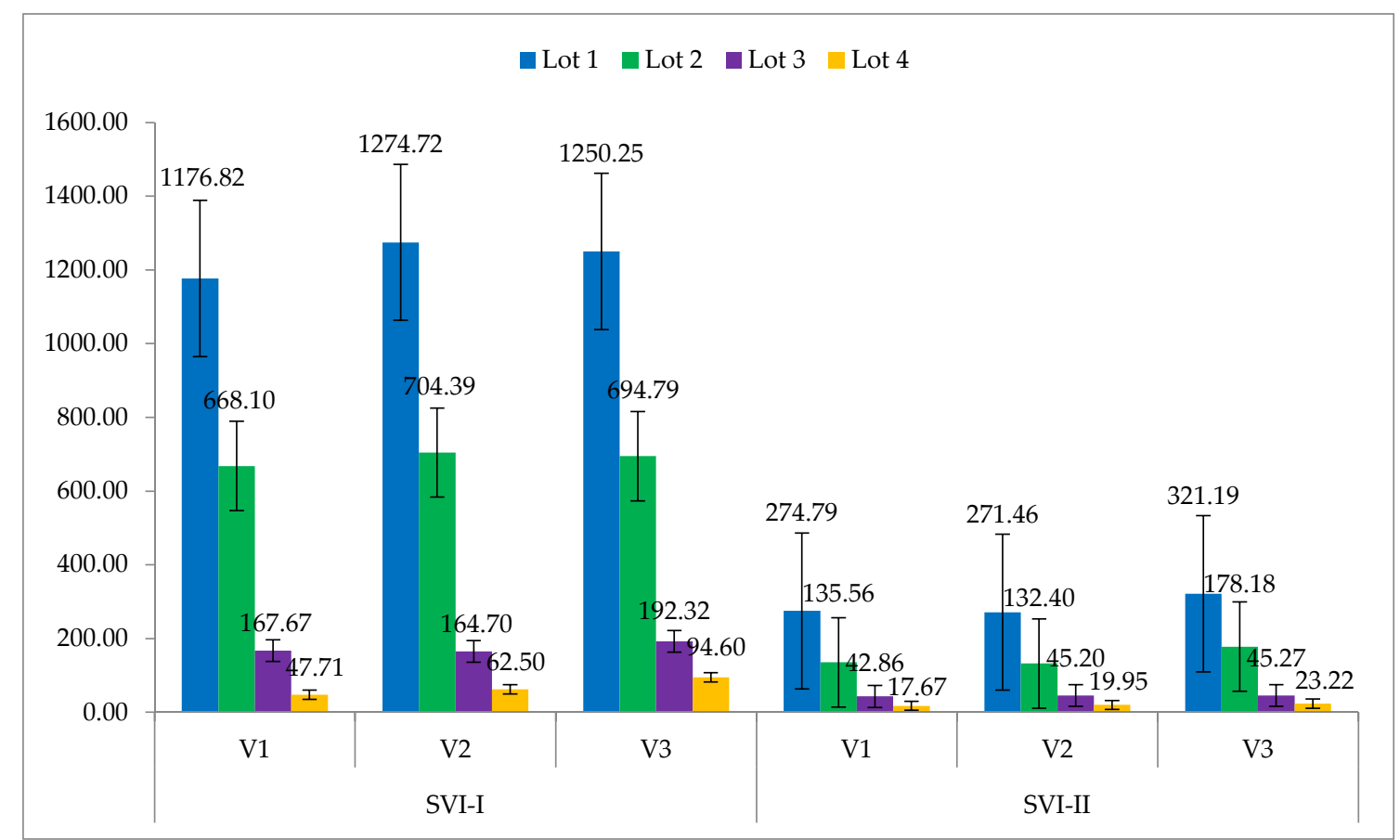

Figure 2. Effect of seed ageing on seed vigour indices. $\mathrm{V}_{1}-$ Hisar-2; $\mathrm{V}_{2}-$ Hisar onion $3 ; \mathrm{V}_{3}-$ Hisar onion 4; Lot 1-Fresh seed; Lot 2-One year old seed; Lot 3-Two year old seed; Lot 4-Three year old seed. Whereas, the y-axis indicates the scale (up to 1600) of the vigour indices.

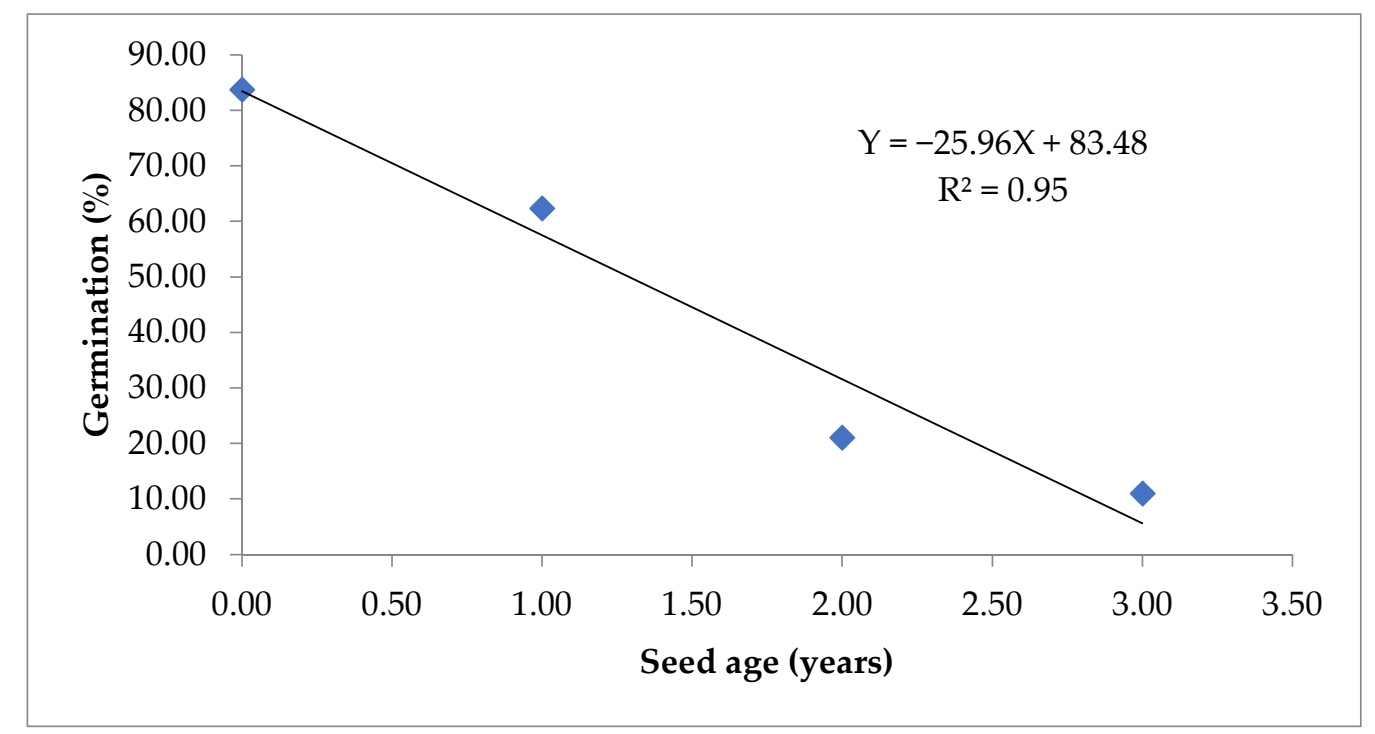

Figure 3. Simple linear regression between seed age and germination.

\subsection{Simulation of Natural Ageing and Artificial Ageing}

The accelerated ageing test (AAT) was performed to simulate the natural ageing with artificial methods. It was observed that $48 \mathrm{~h}$ AAT reduced the germination $\%$ of fresh onion seed up to $64.62-65.92 \%$, which is equal to one year of natural ageing under ambient storage conditions (Figure 1A). Out of the three cultivars, Hisar Onion- $4\left(V_{3}\right)$ had the highest germination $(65.92 \%)$, which leads to the conclusion that it is the best storer among the three cultivars. AAT has a high negative correlation $(r=-0.96, p<0.05)$ with the age of onion seed (Table 1$)$. 


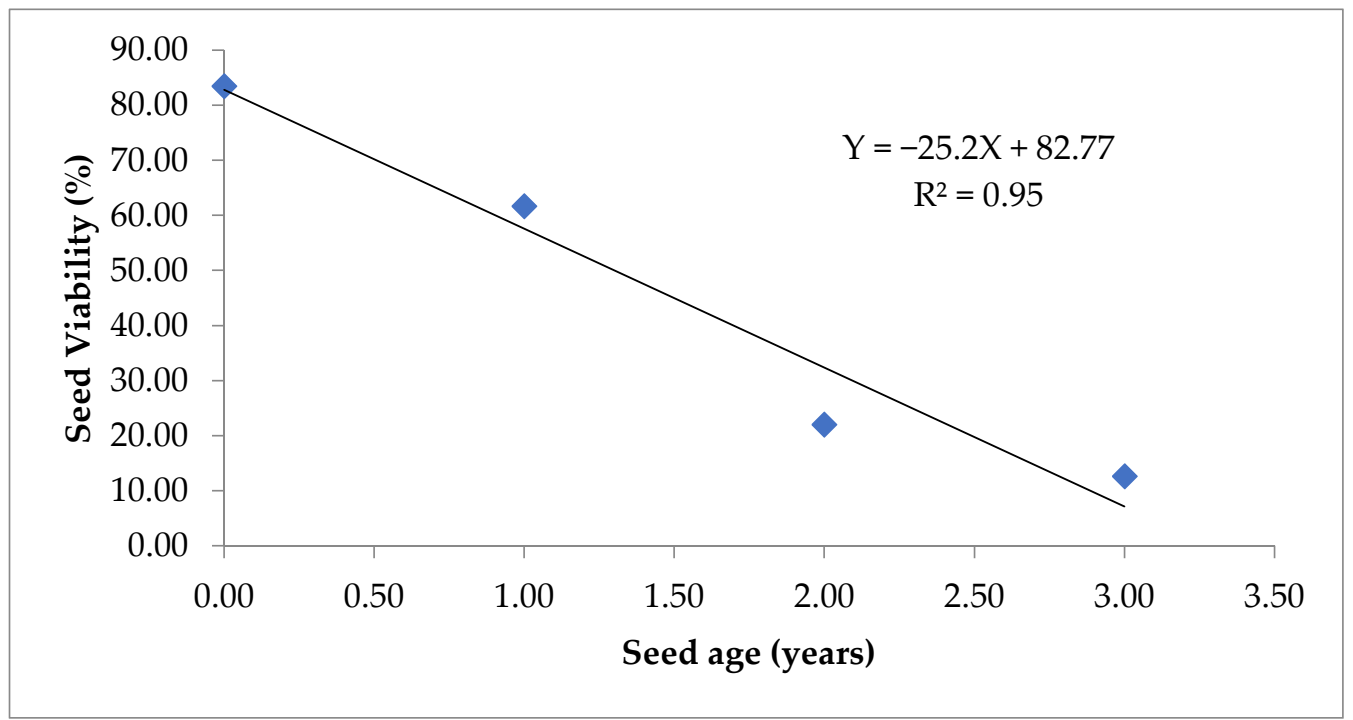

Figure 4. Simple linear regression between seed age and seed viability (\%).

\subsection{Biochemical Parameters}

The seed biochemical parameters, namely electrical conductivity (EC), dehydrogenase activity (DHA) and antioxidants sodium peroxidase (SOD), catalase (CAT) and peroxidase (POD) were assessed in differentially aged onion seeds. The EC activity increased significantly as the duration of ageing increased, and maximum EC of seed leachates was observed after three years of storage (Lot 4); among the cultivars, Hisar-2 $\left(\mathrm{V}_{1}\right)$ showed higher seed leachate EC than others (Figure 5A). Moreover, EC showed significant $(p<0.05)$ positive correlation with seed age and negative correlation with other seed attributes (Table 1).

The specific activity of the dehydrogenase (DHA) enzyme decreased significantly in all three cultivars of onion with an increase in natural ageing. The maximum DHA activity $\left(0.851 \mathrm{OD} \cdot \mathrm{g}^{-1} \cdot \mathrm{m}^{-1}\right)$ was observed in the fresh seed of $\mathrm{V}_{1}$, followed by $\mathrm{V}_{3}\left(0.862 \mathrm{OD} \cdot \mathrm{g}^{-1} \cdot \mathrm{m}^{-1}\right)$ (Figure $\left.5 \mathrm{~B}\right)$. The loss of dehydrogenase enzyme activity are parallels with loss in onion seed viability and vigour, which showed that this enzyme is used to access the viability of the seeds. The production of some respiratory enzymes is an indication of embryo viability and declining of dehydrogenase in seeds may contribute to respiratory failure leads to loss of seed viability. Biochemical deterioration of embryo axes of onion seed also downgrade the defence-related proteins (antioxidants system) of seed, namely CAT, SOD and POD. The CAT, POD and SOD were recorded in differentially aged onion seed lots and enzyme activity decreased with ageing in all the genotypes (Figure 5C,D). The maximum CAT $\left(0.166 \mathrm{mg} \cdot\right.$ protein $\left.^{-1} \cdot \mathrm{min}^{-1}\right)$ was recorded in Hisar Onion-3 $\left(\mathrm{V}_{2}\right)$, and maximum SOD $\left(0.103 \mathrm{mg} \cdot\right.$ protein $\left.^{-1} \cdot \mathrm{min}^{-1}\right)$ and POD $\left(35.18 \mathrm{mg} \cdot\right.$ protein $\left.^{-1} \cdot \mathrm{min}^{-1}\right)$ activity was recorded in Hisar Onion-2 $\left(\mathrm{V}_{1}\right)$ in freshly harvested seed lot, while minimum activity $(0.023)$ was observed in three years aged seed lot. CAT, SOD and DHA have a high negative correlation with seed age, while POD had a perfect negative correlation with seed age (Table 1). 


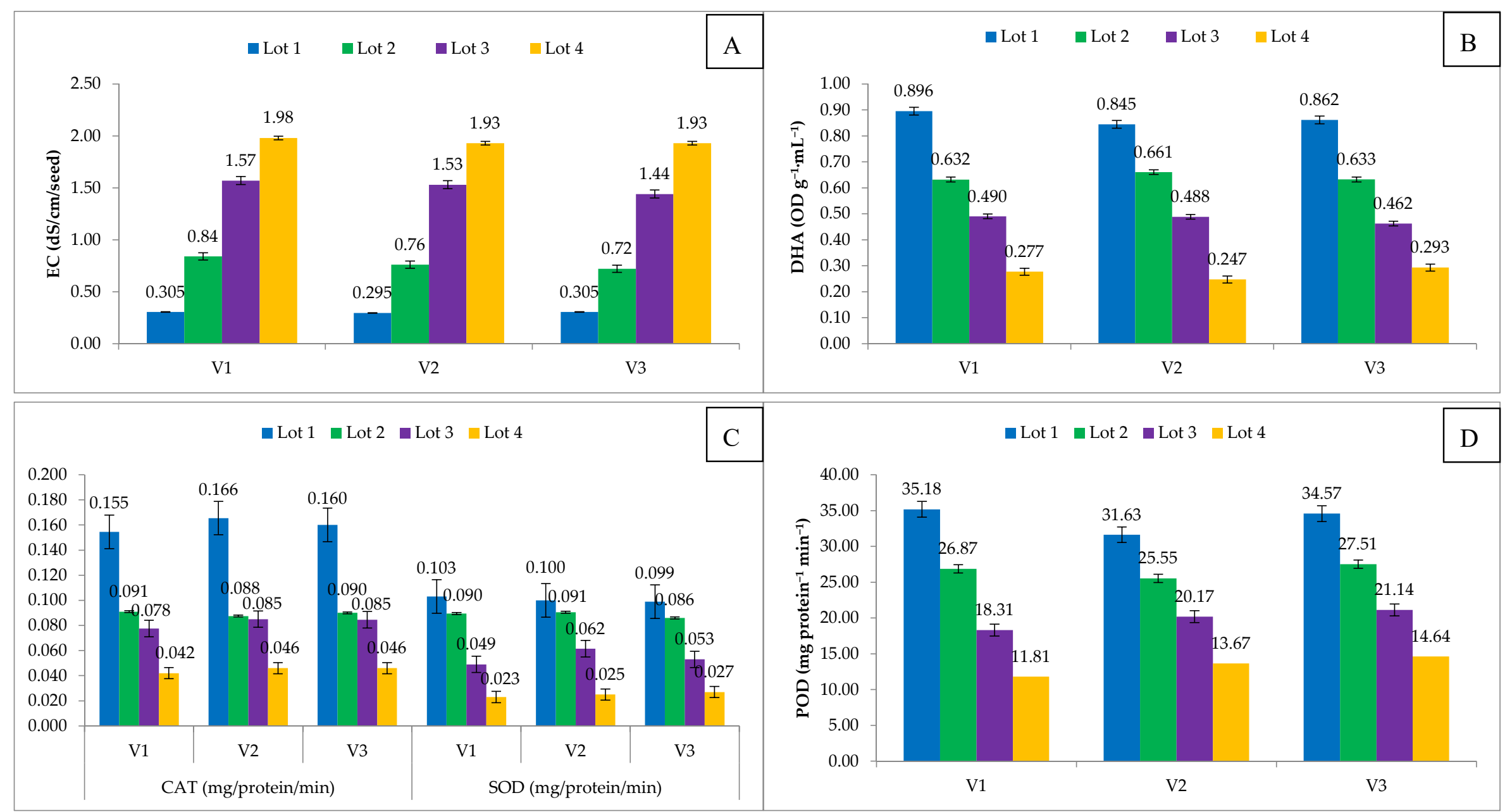

Figure 5. Effect of seed ageing on (A) Electrical conductivity; (B) DHA activity; (C) CAT and SOD activity; (D) POD activity. $\mathrm{V}_{1}-\mathrm{Hisar}_{2}$; $\mathrm{V}_{2}-\mathrm{Hisar}$ Onion-3; $\mathrm{V}_{3}$-Hisar Onion-4; Lot 1—Fresh seed; Lot 2—One-year-old seed; Lot 3-Two-year-old seed; Lot 4-Three-year-old seed. 


\subsection{Seedling Emergence Index and Seedling Establishment (\%)}

Seedling emergence index (SEI) and seedling establishment (SE) decreased as the period of natural ageing increased in all the three genotypes. Highest $S E(67.5 \%)$ was observed in $V_{2}$ and $V_{3}$, however in the with the progression of the age of seed $V_{2}$ performed better than $V_{3}$ (Figure 1D). The positive correlation $(r=0.995, p<0.05)$ between germination percentage (GP) and seedling establishment (SE) showed that natural ageing reduced the germination of seed both under laboratory and field conditions (Table 1). Highest SEI was also recorded in the case of $V_{2}$ with a value of 6.63 (Figure 6). Also a simple linear regression model explains $91 \%$ variation $\left(R^{2}=0.91\right)$ in seedling emergence with ageing in seed (Figure 7). SEI also has a significant correlation $(r=0.992, p<0.05)$ with germination percent (Table 1$)$.

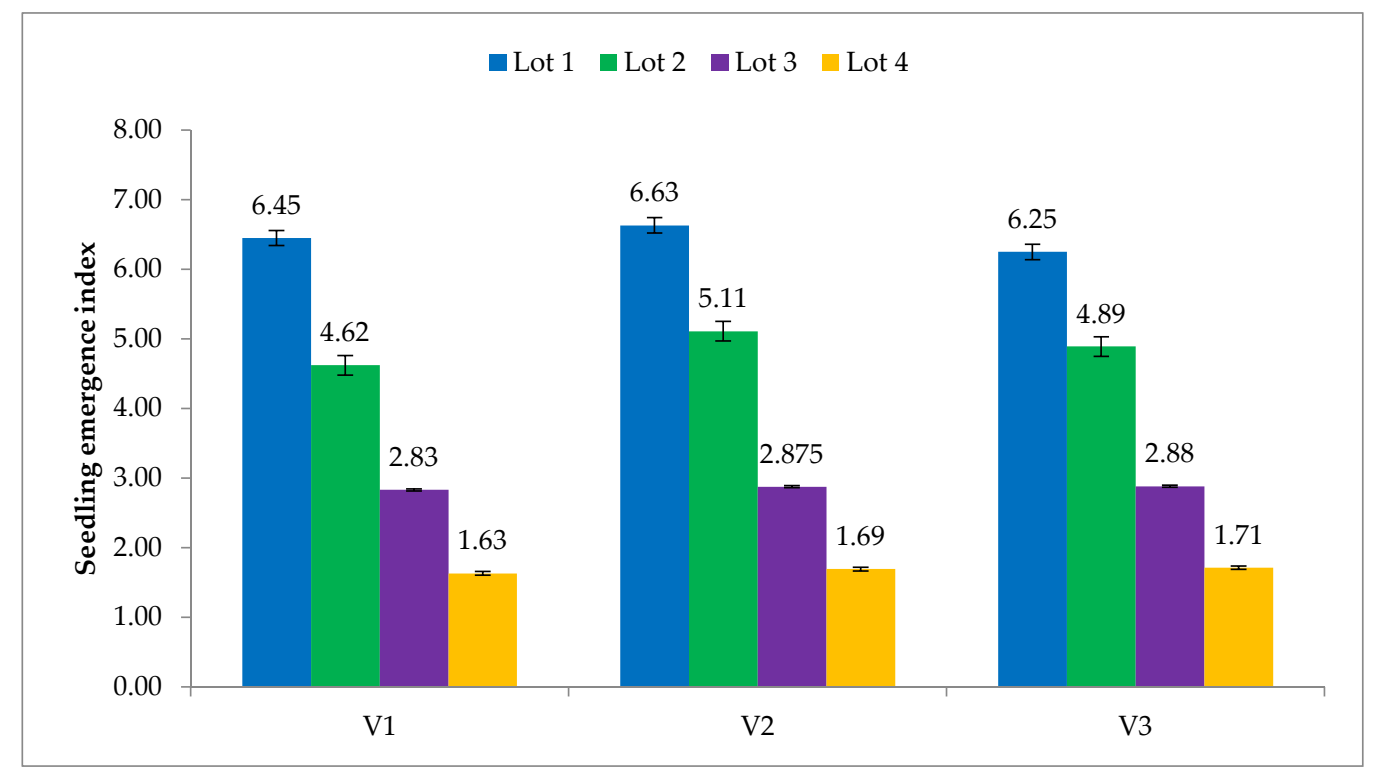

Figure 6. Effect of seed ageing on seedling emergence index. $\mathrm{V}_{1}-$ Hisar-2; $\mathrm{V}_{2}-$ Hisar Onion- 3 ; $\mathrm{V}_{3}$-Hisar Onion-4; Lot 1-Fresh seed; Lot 2-One-year-old seed; Lot 3-Two-year-old seed; Lot 4-Three-year-old seed.

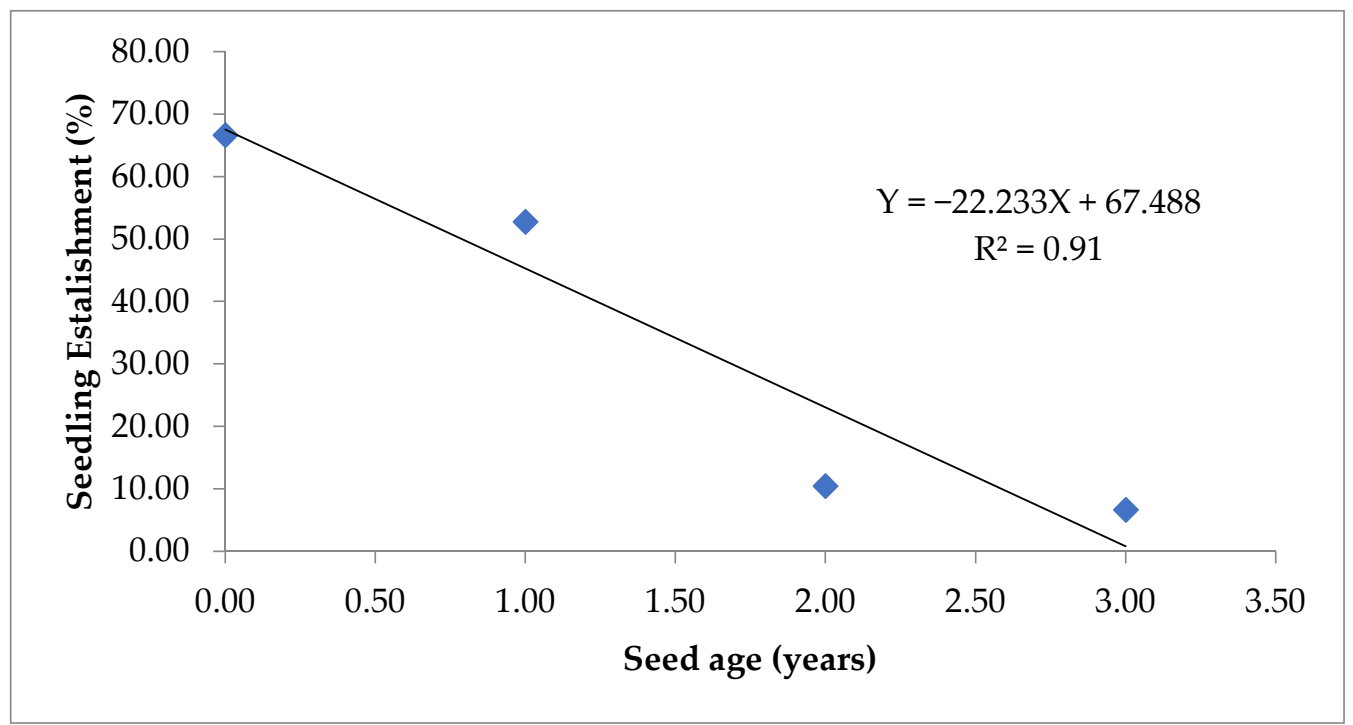

Figure 7. Simple linear regression between seed age and seedling establishment (\%). 


\section{Discussion}

The decrease in seed physiological parameters with relation to natural ageing in different cultivars showed that onion seeds, in general, are poorer storer [33]. Various researchers reported several reasons for the decrease in germination and viability, namely, chromosomal aberrations, $\alpha$-amylase activity and carbohydrate contents [17] and denaturation of proteins [34]. However, it was reported that when ageing progresses beyond a critical period, then there is a carryover effect of ageing, which significantly reduces germination and radical length [35]. The results recorded in this study are similar to result of other workers, namely in garden pea [36]; in soybean [37]; in pea [38]; in turnip [39]; in mustard [40] and chickpea [41].

Simulation of natural ageing with AAT is a useful tool for the maintenance of different genotypes in the seed bank [42]. The test simulates the cell damage during long term storage and thus is helpful in obtaining information on seed vigour [43]. During the accelerated ageing, seed lot is exposed to high temperature and high relative humidity, which leads to the loss of vigour and eventually viability, and it is an excellent method to determine the vigour changes during seed storage [44]. Hence, AAT can prove to be a useful tool in seed quality control programmes. Fabrizius et al. [45] also confirmed the possibility of predicting the actual germination of soybean seed during natural ageing by applying the accelerated ageing test. When compared with the seed germination in naturally aged seed lot, germination in AAT provides a baseline for the studies where the naturally aged seed is not available [46]. In naturally aged seed with the decline in germination percentage enzyme activity also decreases. Thus the germination is a good indicator for the biochemical changes in case of AAT also. Further studies on the biochemical changes in onion seed after AAT can be conducted. Such studies have been undertaken in carrot, cucumber, radish and peanut [47-50].

As the age of the seed, EC increases and enzyme activity decreases, which is evident from the low germination, viability and vigour of the seed. Blackman and Leopold [51] also proposed an ageing model for onion seed which states that the ageing is accompanied with denaturation and degradation of proteins, enzyme inactivation, breakdown of phospholipids and depository lipids, lipid peroxidation and alteration of membrane permeability. Similarly, it was also reported increased peroxidation and low antioxidant enzyme activity with the ageing of seed [52-54]. The high seed leachates EC is the indications of seed deterioration process because outer and inner membranes of cells appeared as potential targets during seed ageing and it may cause alteration of lower plasma membrane ATPase activity [55]. In studies on peanut [50], watermelon [56], soybean [57], sunflower [58] and safflower [59] it was reported that an increase in electrolyte leakage is associated with a decrease of seed germination. It was also reported that during the seed deterioration amadori rearrangements are taking place in the dry seed system, which involves interactions between reducing sugar and protein amino groups resulting into formation of glycated proteins [60]. Later on, during Millard reaction, different amadori products interact with each other and formed polymeric brown coloured products [61]. Therefore, lipid peroxidation and the loss of membrane phospholipids are significant causes of seed ageing under natural ageing conditions [5]. SOD serves a protective role in respiring cells through its elimination of the reactive superoxide radical [62]. The SOD activity can maintain a low concentration of superoxide in the cells and prevent the formation of harmful oxidative products in plant cells [63].

Similarly, CAT and POD activity decreased with the ageing of seed in all cultivars, but Hisar Onion-3 showed a higher amount of activity after a certain period of ageing. These results support the hypothesis of [52], which states that a decrease in antioxidant enzymes activity is linked to increased lipid peroxidation and accelerated ageing. Previously, a positive relationship between antioxidant enzyme capacity and the vigour of the seed was also determined [53,54]. Loycrajjou et al. [64] reported that ageing induced deterioration increases the extent of protein oxidation, and loss of functional properties of proteins and enzymes. The experimental results obtained from this study show similarities with the effects of the ageing model of onion seeds developed by Blackman et al. [51] which suggest that ageing coincides with protein denaturation, degradation, inactivation of enzymes, the breakdown of phospholipids, lipid peroxidation and alteration of membrane permeability. 
Scialabba et al. [65] reported that peroxidase activity decreased in aged seeds as compared to fresh seeds in radish. Pallavi et al. [66] studied that sharp decline in peroxidase enzyme during ageing in sunflower. Peroxidase and catalase activities were found higher in younger seeds of Chenopodium rubrum [67]. Verma et al. [40] observed that the dehydrogenase activity was reduced as the ageing progressed and was found lowest after four years of storage in Brassica spp. It seems possible that these effects are due to damage to RNA synthesis, which ultimately leads to decreased synthesis of proteins and inactivation of enzymes [68]. The attack of reactive oxygen species (ROS) on all enzymes causes damage to the molecules and also reduces sugar concentration in cells, which can play a significant role in the reduction of antioxidant activity $[14,69]$. Free radicals form during the storage of the seed, even if oxygen is present in trace amounts. Fatty acid hydroperoxide formation takes place from the decomposition of unsaturated fatty acid moieties, which further breakdown to alkoxyl radicals [70]. In aged seeds where active enzymes scavenging free radicals are low, the degradation products of lipid peroxidation accumulate, which ultimately leads to a loss in seed viability [71]. Further, this is supported by the positive correlation between the enzymes and seed viability (Table 1). The decrease in the SE and SEI might be due to the reduction of enzymes ( $\alpha$-amylase and other hydrolytic enzymes) [27]; lipid peroxidation and other biochemical degradation that take place during storage of seeds $[72,73]$. Seedling establishment is based on the different heterogeneous conditions of open field, and it's also positively correlated with all seed physiological parameters.

\section{Conclusions}

This study explores the impact of seed ageing on the physiology and biochemistry of seed and concludes that seed age is negatively correlated with these quality parameters except for EC with which it has a positive correlation. Free radicals in the ageing seeds are responsible for the deterioration of seed membrane, which leads to an increase in seed leachates and consequently EC. In the event of scarcity of antioxidant enzymes, namely DHA, CAT, POD and SOD, these free radicals lead to a decline in the seed viability in the ageing seed. The interplay of these factors leads to the ultimate decrease in physiological attributes of seed, and thus storage capacity of seed is affected. A comparison between germination under natural ageing and AAT can also be made from this study, which will form basis for drawing appropriate conclusions in further studies based on the artificially aged seed. AAT will prove to be an indispensable tool for quality control measures in commercial seed production programmes. This study extends our understanding of the role of antioxidant enzymes in seed ageing as well as their influence on seed physiology in onion seed, the aspects which were thoroughly explored only in case of seeds of field crops.

Author Contributions: B.S.D. and N.S.B. conceived of and designed the project. B.S.D. supervised the study. N.S.B. and P.K. performed the experiments and analyzed the data. N.S.B. and P.K. wrote the paper. P.K. corrected the final draft. All authors read and approved the final manuscript.

Funding: This research received no external funding.

Acknowledgments: Authors are thankful to the anonymous reviewers for their careful reading of the manuscript and for providing insightful suggestions.

Conflicts of Interest: The authors declare no conflict of interest.

\section{References}

1. Horticultural Statistics at Glance 2017; Ministry of Agriculture \& Farmers Welfare, Government of India: New Delhi, India, 2017.

2. FAOSTAT. Available online: http://www.fao.org/faostat/en/\#data/QC (accessed on 25 May 2019).

3. Chengappa, P.G.; Manjunatha, A.V.; Dimble, V.; Shah, K. Competitive Assessment of Onion Markets in India; Institute for Social and Economic Change, Competition Commision of India: Bangalore, India, 2012; p. 86.

4. Bishaw, Z.; Niane, A.A.; Gan, Y. Quality Seed Production. In Lentil: An Ancient Crop for Modern Times; Yadav, S.S., McNeil, D.L., Stevenson, P.C., Eds.; Springer: Dordrecht, The Netherlands, 2007; pp. 349-383. ISBN 978-1-4020-6313-8. 
5. Falcinelli, M. Temperate Forage Seed Production. J. New Seeds 1999, 1, 37-66. [CrossRef]

6. Verge, X.P.C.; De Kimpe, C.; Desjardins, R.L. Agricultural production, greenhouse gas emissions and mitigation potential. Agric. For. Meteorol. 2007, 142, 255-269. [CrossRef]

7. Federico, G. Feeding the World: An Economic History of Agriculture, 1800-2000; Princeton University Press: Princeton, NJ, USA, 2010; Volume 34.

8. Mayer, A.M.; Poljakoff-Mayber, A. The Germination of Seeds: Pergamon International Library of Science, Technology, Engineering and Social Studies, 3rd ed.; Elsevier: Amsterdam, The Netherlands, 1982.

9. Delouche, J.C.; Baskin, C.C. Accelerated aging techniques for predicting the relative storability of seed lots. Seed Sci. Technol. 1973, 1, 427-452.

10. George, R.A. Vegetable Seed Production, 3rd ed.; CABI: Wallingford, UK, 2009.

11. Pritchard, H.W.; Nadarajan, J. Cryopreservation of orthodox (desiccation tolerant) seeds. In Plant Cryopreservation: A Practical Guide; Reed, B.M., Ed.; Springer: New York, NY, USA, 2008; pp. 485-501.

12. Probert, R.; Adams, J.; Coneybeer, J.; Crawford, A.; Hay, F. Seed quality for conservation is critically affected by pre-storage factors. Aust. J. Bot. 2007, 55, 326-335. [CrossRef]

13. Balaban, R.S.; Nemoto, S.; Finkel, T. Mitochondria, oxidants, and aging. Cell 2005, 120, 483-495. [CrossRef] [PubMed]

14. Murthy, U.M.N.; Kumar, P.P.; Sun, W.Q. Mechanisms of seed ageing under different storage conditions for Vigna radiata (L.) R. Wilczek: Lipid peroxidation, sugar hydrolysis, Maillard reactions and their relationship to glass state transition. J. Exp. Bot. 2003, 54, 1057-1067. [CrossRef] [PubMed]

15. McDonald, M.B. Seed deterioration: Physiology, repair and assessment. Seed Sci. Technol. 1999, $27,177-237$.

16. Walters, C. Understanding the mechanisms and kinetics of seed ageing. Seed Sci. Res. 1998, 8, $223-244$. [CrossRef]

17. Bailly, C. Active oxygen species and antioxidants in seed biology. Seed Sci. Res. 2004, 14, 93-107. [CrossRef]

18. McDonald, M.B. Orthodox seed deterioration and its repair. In Handbook of Seed Physiology Applications to Agriculture; Benech-Arnold, R.L., Sanchez, R.A., Eds.; Food Products Press: New York, NY, USA, 2004; pp. 273-304.

19. Lehner, A.; Mamadou, N.; Poels, P.; Come, D.; Bailly, C.; Corbineau, F. Changes in soluble carbohydrates, lipid peroxidation and antioxidant enzyme activities in the embryo during ageing in wheat grains. J. Cereal Sci. 2008, 47, 555-565. [CrossRef]

20. Goel, A.; Goel, A.K.; Sheoran, I.S. Changes in oxidative stress enzymes during artificial ageing in cotton (Gossypium hirsutum L.) seeds. J. Plant. Physiol. 2002, 160, 1093-1100. [CrossRef]

21. Wang, G.; Huang, J.; Gao, W.; Lu, J.; Li, J.; Liao, R.; Jaleel, C.A. The effect of high-voltage electrostatic field (HVEF) on aged rice (Oryza sativa L.) seeds vigor and lipid peroxidation of seedlings. J. Electrost. 2009, 67, 759-764. [CrossRef]

22. Finch-Savage, W.E.; Bassel, G.W. Seed vigour and crop establishment: Extending performance beyond adaptation. J. Exp. Bot 2016, 67, 567-591. [CrossRef]

23. ISTA. International Rules for Seed Testing 2015; International Seed Testing Association: Bassersdorf, Switzerland, 2015.

24. Abdul-Baki, A.A.; Anderson, J.D. Physiological and biochemical deterioration of seeds. In Seed Biology; Kozlowski, T.T., Ed.; Academic Press: New York, NY, USA, 1972; pp. 283-315.

25. Moore, R.P. Tetrazolium stain for assessing seed quality. In Seed Ecology; Heydecker, W., Ed.; The Pennsylvania State University: University Park, PA, USA, 1973; pp. 347-366.

26. Dadlani, M.; Agrawal, P.K. Techniques in Seed Science and Technology; South Asian Publishers: New Delhi, India, 1987; pp. 103-104.

27. Aebi, H. Catalase in vitro. Meth. Enzymol. 1983, 105, 121-126. [CrossRef]

28. Rao, M.V.; Paliyath, G.; Ormrod, D.P. Ultraviolet-B- and ozone-induced biochemical changes in antioxidant enzymes of Arabidopsis thaliana. Plant. Physiol. 1996, 110, 125-136. [CrossRef]

29. Kittock, D.L.; Law, A.G. Relationship of seedling vigour to respiration and tetrazolium chloride reduction by germinating wheat seeds. Agron. J. 1968, 60, 286-288. [CrossRef]

30. Dhindsa, R.H.; Plumb-Dhindsa, P.; Thorpe, T.A. Leaf senescence correlated with increased level of membrane permeability, lipid peroxidation and decreased level of SOD and CAT. J. Exp. Bot. 1981, 32, 93-101. [CrossRef]

31. Maguire, J.D. Speed of germination aid in selection and evaluation for seedling emergence and vigour. Crop. Sci. 1962, 2, 176-177. [CrossRef] 
32. Cochran, W.G.; Cox, G.M. Experimental Designs, 2nd ed.; Wiley: New York, NY, USA, 1957; pp. 1-611.

33. Demirkaya, M.; Dietz, K.-J.; Sivritepe, H.Ö. Changes in antioxidant enzymes during ageing of onion seeds. Not. Bot. Horti Agrobot. Cluj-Napoca 2010, 38, 49-52. [CrossRef]

34. Nautiyal, A.R.; Thapliyal, A.P.; Purohit, A.N. Seed viability, Protein changes: Accompanying loss of viability in Shorea robusta. Seed Sci. Technol. 1985, 13, 83-86.

35. Khan, M.M.; Iqbal, M.J.; Abbas, M.; Usman, M. Effect of accelerated ageing on viability, vigour and chromosomal damage in pea (Pisum sativum L.) seeds. J. Agric. Sci. 2003, 40, 50-54.

36. Pandita, V.K.; Shantha, N.; Nagarajan, S. Germination behaviour and field performance of garden pea (Pisum sativum) in relation to seed ageing. Ind. J. Agric. Sci. 2002, 72, 213-215.

37. Gupta, A.; Aneja, K.R. Seed deterioration in soybean varieties during storage-physiological attributes. Seed Res. 2004, 32, 26-32.

38. Kumar, R.; Nagarajan, S.; Rana, S.C. Effect of natural ageing under controlled storage on seed quality and yield performance of field pea cv. DMR-7. Seed Res. 2004, 32, 96-97.

39. Khan, M.M.; Iqbal, M.J.; Abbas, M. Loss of viability correlates with membrane damage in aged turnip (Brassica rapa) seeds. Seed Sci. Technol. 2005, 33, 517-520. [CrossRef]

40. Verma, S.S.; Verma, U.; Tomer, R.P.S. Studies on seed quality parameters in deteriorating seeds in brassica (Brassica campestris). Seed Sci. Technol. 2003, 31, 389-396. [CrossRef]

41. Kapoor, N.; Arya, A.; Siddiqui, M.A.; Amir, A.; Kumar, H. Seed deterioration in chickpea (Cicer arietinum L.) under accelerated ageing. AsianJ. Plant. Sci. 2010, 9, 158-162. [CrossRef]

42. Fu, Y.-B.; Ahmed, Z.; Diederichsen, A. Towards a better monitoring of seed ageing under ex situ seed conservation. Conserv. Physiol. 2015, 3. [CrossRef]

43. Wu, X.; Ning, F.; Hu, X.; Wang, W. Genetic Modification for Improving Seed Vigor Is Transitioning from Model Plants to Crop Plants. Front. Plant. Sci. 2017, 8. [CrossRef]

44. Tian, X.; Song, S.; Lei, Y. Cell death and reactive oxigen species metabolism during accelerated ageing of soybean axes. Russ. J. Plant. Physiol. 2008, 55, 33-40. [CrossRef]

45. Fabrizius, E.; TeKrony, D.; Egli, D.B.; Rucker, M. Evaluation of a viability model for predicting soybean seed germination during warehouse storage. Crop. Sci. 1999, 39, 194-201. [CrossRef]

46. Yin, X.; He, D.; Gupta, R.; Yang, P. Physiological and proteomic analyses on artificially aged Brassica napus seed. Front. Plant. Sci. 2015, 6. [CrossRef]

47. Jain, N.; Koopar, R.; Saxena, S. Effect of accelerated ageing on seeds of radish (Raphanus sativus L.). Asian J. Plant. Sci. 2006, 5, 461-464.

48. Al-Maskeri, A.Y.; Khan, M.M.; Khan, I.A.; Al-Habsi, K. Effect of accelerated ageing on viability, vigour (RGR), lipid peroxidation and leakage in carrot (Daucus carota L.) seeds. Int. J. Agric. Biol. 2003, 5, 580-584.

49. Al-Maskri, A.; Khan, M.M.; Al-Manthery, O.; Al-Habsi, K. Effect of accelerated ageing on lipid peroxidation leakage and seedling vigour (RGR) in cucumber (Cucumis sativus L.) seeds. Pak. J. Agric. Sci. 2002, 39, 330-337.

50. Sung, J.M.; Jeng, T.L. Lipid peroxidatioin and peroxide-scavenging enzymes associated with accelerated aging of peanut seed. Physiol. Plant. 1994, 91, 51-55. [CrossRef]

51. Blackman, S.; Leopold, A.C. Chemical and physical factors in seed deterioration, basic and applied aspects of seed biology. In Proceedings of the IV International Workshop on Seeds, Angers, France, 20-24 July 1992; pp. 731-737.

52. Bailly, C.; Benamar, A.; Corbineau, F.; Côme, D. Changes in malondialdehyde content and in superoxide dismutase, catalase and glutathione reductase activities in sunflower seeds as related to deterioration during accelerated aging. Physio. Plant. 1996, 97, 104-110. [CrossRef]

53. Bailly, C.; Benamar, A.; Corbineau, F.; Côme, D. Antioxidant systems in sunflower (Helianthus annuus L.) seeds as affected by priming. Seed Sci. Res. 2000, 10, 35-42. [CrossRef]

54. Bailly, C.; Bogatek-Leszczynska, R.; Côme, D.; Corbineau, F. Changes in activities of antioxidant enzymes and lipoxygenase during growth of sunflower seedlings from seeds of different vigour. Seed Sci. Res. 2002, 12, 47-55. [CrossRef]

55. Bardel, J.; Louwagie, M.; Jaquinod, M.; Bourguignon, J. A survey of plant mitochondria proteome in relation with development. Proteomics 2002, 2, 880-898. [CrossRef] 
56. Chiu, K.Y.; Wang, C.S.; Sung, J.M. Lipid peroxidation and peroxide scavenging enzymes associated with accelerated aging and hydration of watermelon seeds differing in ploidy. Physiol. Plant. 1995, 94, 441-446. [CrossRef]

57. Sung, J.M. Lipid peroxidation and peroxide scavenging in soybean seeds during ageing. Physiol. Plants 1996, 97, 85-89. [CrossRef]

58. Kibinza, S.; Vinel, D.; Come, D.; Bailly, C.; Corbineau, F. Sunflower seed deterioration as related to moisture content during ageing, energy metabolism and active oxygen species scavenging. Physiol. Plant. 2006, 128, 496-506. [CrossRef]

59. Zamani, A.; Sadat Nouri, S.A.; Tavakol Afshari, R.; Iran Nezhad, H.; Ali Akbari, G.; Tavakoli, A. Lipid peroxidation and antioxidant enzymes activity under natural and accelerated ageing in safflower (Carthamus tinctorius L.) seed. Iran. J. Agric. Sci. 2010, 41, 545-554.

60. Wettlaufer, S.; Carl Leopold, A. Relevance of Amadori and Maillard Products to Seed Deterioration. Plant Physiol. 1991, 97, 165-169. [CrossRef]

61. Bernal-Lugo, I.; Leopold, A.C. Changes in soluble carbohydrates during seed storage. Plant Physiol. 1992, 98, 1207-1210. [CrossRef]

62. Blokhina, O.; Virolainen, E.; Fagerstedt, K.V. Antioxidants, oxidative damage and oxygen deprivation stress: A Review. Ann. Bot. 2003, 91, 179-194. [CrossRef]

63. Alscher, R.G.; Erturk, N.; Heath, L.S. Role of superoxide dismutase (SODs) in controlling oxidative stress in plants. J. Exp. Bot. 2002, 53, 1331-1341. [CrossRef]

64. Loycrajjou, L.Y.; Steven, P.C.; Groot Belghazi, M.; Job, C.; Job, D. Proteome wide characterization of seed ageing in Arabidopsis. A comparison between artificial and natural ageing. Prot. Pl. Phy. 2008, 148, 620-641. [CrossRef]

65. Scialabba, A.; Bellani, L.M.; Dell'aquila, A. Effects of ageing on peroxidase activity and localization in radish (Raphanus sativus L.) seeds. Eur. J. Histochem. 2002, 46, 351-358. [CrossRef]

66. Pallavi, M.; Sudheer, S.K.; Dangi, K.S.; Reddy, A.V. Effect of seed ageing on physiological, biochemical and yield attributes in sunflower (Helianthus annus L.) cv. Morden. Seed Res. 2003, 31, 161-168.

67. Mitrovic, A.; Ducic, T.; Rajlic, I.L.; Radotic, K.; Zivanovic, B. Changes in Chenopodium rubrum seeds with ageing. Ann. New York Acad. Sci. 2005, 1048, 505-508. [CrossRef]

68. Zhu, F.; Zhou, Y.-K.; Ji, Z.-L.; Chen, X.-R. The Plant Ribosome-Inactivating Proteins Play Important Roles in Defense against Pathogens and Insect Pest Attacks. Front. Plant. Sci. 2018, 9. [CrossRef]

69. Tabatabaei, S.A. The changes of germination characteristics and enzyme activity of barley seeds under accelerated ageing. Cerc. Agron. Mold. 2015, 48, 61-67.

70. Akhter, F.N.; Kabir, G.; Mannan, M.A.; Shaheen, N.N. Ageing effect of wheat and barley seeds upon germination mitotic index and chromosomal damage. J. Islam Acad. Sci. 1992, 5, 44-48.

71. Subedi, K.D.; Ma, B.L. Seed priming does not improve corn yield in a humid temperate environment. Agron. J. 2005, 97, 211-218. [CrossRef]

72. Hopin, A.; Huang, S.W.; Frankel, E.M. Effect of $\alpha$-tocopherol and trolox on the decomposition of methyl linoleate hydroperoxide. Lipids 1996, 31, 357-365.

73. Rao, R.G.S.; Singh, P.M.; Rai, M. Storability of onion seeds and effect of packaging and storage conditions on viability and vigour. Sci. Hort. 2006, 110, 1-6. [CrossRef]

(C) 2019 by the authors. Licensee MDPI, Basel, Switzerland. This article is an open access article distributed under the terms and conditions of the Creative Commons Attribution (CC BY) license (http://creativecommons.org/licenses/by/4.0/). 